Yayın Geliş Tarihi: 06.12.2020

Yayına Kabul Tarihi: 07.05.2021

Online Yayın Tarihi: 30.06.2021

http://dx.doi.org/10.16953/deusosbil.836709
Dokuz Eylül Üniversitesi

Sosyal Bilimler Enstitüsü Dergisi

Cilt: 23, Say1: 2, Y11: 2021, Sayfa: 853-867

ISSN: 1302-3284 E-ISSN: 1308-0911

Araştırma Makalesi

\title{
MANAGEMENT AND LEADERSHIP TYPE IN AUTOMOTIVE INDUSTRY: VIEW FROM TURKEY
}

Kă̆an OKATAN*

\begin{abstract}
'Management' and 'leadership' culture in automotive industry which has an important place in Turkey's exports, was measured with examples. Organizational culture was measured according to the typologies of 'market', 'adhocracy', 'clan' and 'hierarchy'. 'Competing values framework' was used as a measurement tool on the collected first hand data. The use of the competing values framework was also enabled the identification of general organizational culture in exemplary corporations. As a result of the study, it was demonstrated that dominance of 'market' type culture which is customer and external oriented and also focuses on success and competition, in the management and leadership at automotive industry. The market culture type has been observed as the top culture type, especially in the 'organizational leadership'dimensions of all sample corporations. In light of these results, the study showed us that the perception of success in management and leadership is intensely focused on 'business outcomes'.
\end{abstract}

Keywords: Management, Leadership, Organizational Culture, Production Management, Technology and Innovation Management.

\section{OTOMOTIV SEKTÖRÜNDE YÖNETIM VE LIDERLIKK TÜRÜ: TÜRKIYYE'DEN GÖRÜNÜM}

$\ddot{O} z$

Bu çalışmada Türkiye ihracatında önemli bir yere sahip olan otomotiv sektöründe 'yönetim' ve 'liderlik' kültürü örneklerle ölçülmüştür. Örgütsel kültür, 'pazar', 'adhokrasi', 'klan' ve 'hiyerarşi' tipolojilerine göre ölçülmüştür. İlk elden toplanan veriler üzerinde bir ölçüm aracı olarak 'rekabetçi değerler çerçevesi' kullanılmıştır. 'Rekabetçi değerler çerçevesinin' kullanılması, örnek şirketlerde genel organizasyon kültürünün tanımlanmasını da sağlamıştır. Çalışma sonucunda otomotiv endüstrisinin yönetiminde ve liderliğinde, müşteri ve dış odaklı, aynı zamanda başarı ve rekabete odaklanan 'pazar' tipi kültürün hakimiyeti ortaya konmuştur. Pazar kültürü türü, özellikle tüm örnek şirketlerin

Bu makale için önerilen kaynak gösterimi (APA 6. Sürüm):

Okatan, K. (2021). Management and leadership type in automotive industry: View from Turkey. Dokuz Eylül Üniversitesi Sosyal Bilimler Enstitüsü Dergisi, 23 (2), 853-867.

* Dr. Öğr. Üyesi., İstanbul Aydın Üniversitesi, İktisadi ve İdari Bilimler Fakültesi, İşletme (İngilizce) Bölümü,

ORCID: 0000-0002-0517-665X, kaganok@gmail.com. 
'organizasyonel liderlik' boyutlarında en üst kültür türü olarak gözlemlenmiştir. Bu sonuçlar ışı̆̆ında çalışma bize, yönetimde ve liderlikte 'başarı' algısının yoğun bir şekilde 'iş sonuçlarına' odaklandığını göstermiş̧tir.

Anahtar Kelimeler: Yönetim, Liderlik, Örgütsel Kültür, Üretim Yönetimi.

\section{INTRODUCTION}

In recent years, many companies have begun to see the whole world as a target market, and this has forced businesses to be more competitive in order to stay in such a large market and to get more shares from this market.

This necessitated the implementation of more effective business strategies. There was more to be focused outside the cost or production activity. Consistently meeting customer expectations has become even more important to remain competitive. Companies have focused on introducing the latest innovations to the market before other companies (Thuengnaitham, 2016).

In order to be able to work successfully in any business environment and to ensure the successful implementation of the business strategies, it is important to understand the values which support the culture and working style of that environment. In addition, appropriate management and leadership are necessary to produce new ideas and to transform them into successful proposals that will increase business success and to implement the actions that will enable them to become reality. In order to understand the success potential of a business, it is necessary to understand its culture, especially the management and leadership dimensions of its culture.

Today, most innovative and successful companies are resource-efficient and well-managed. It is clear that Leadership and management are their main forces on the road of success. This study' $\mathrm{s}$ aim is to identify and present the view of the leadership and management culture types of the selected successful companies from Turkish automotive industry. This study classifies culture types as 'market', 'clan', 'hierarchy' and 'adhocracy' in terms of 'competing values framework'.

Assessment of the culture of the selected companies helps us to answer the following research questions:

- To what extent these types of culture exist in the management and leadership culture of companies?

- Which of the four culture types is the most dominant?

- Is there a relationship between leadership and management dimensions and other dimensions of organizational culture?

This study answers these questions by evaluating the organizational culture based on the data obtained from first-class experts and senior executives of the 
Management and Leadership... $\quad$ DEU Journal of GSSS, Vol: 23, Issue: 2

selected companies. It is also important to underline the importance of automotive industry for Turkey at this point.

\section{Automotive Industry and Turkey}

Turkish automotive sector continues its operations by 12 companies and 18 factories of these 12 companies, 4 are exclusively for automobiles, 6 for commercial vehicles and 2 for both automobiles and commercial vehicles. The automotive industry in Turkey has grown steadily in recent years and is now one of the industries that provide the largest contribution to GDP and export earnings of the country even it has become the first. In 2017. Turkey was already ranked as the 14th world's biggest automotive manufacturing country with a total auto production of almost 1.7 million units. On the other hand, Turkey is the world's 9th and Europe's 2nd largest automotive producer from the commercial vehicle production point of view. 
Okatan, $K$.

DEÜ SBE Dergisi, Cilt: 23, Sayl: 2

Table 1: World's Top Automobile Manufacturing Countries in 2017 (Car Production by Country)

\begin{tabular}{|c|c|c|c|c|}
\hline Rank & Country & Cars & Commercial Vehicles & Total \\
\hline 1 & China & 24.806 .687 & 4.208 .747 & 29.015 .434 \\
\hline 2 & USA & 3.033 .216 & 8.156 .769 & 11.189 .985 \\
\hline 3 & Japan & 8.347 .836 & 1.345 .910 & 9.693 .746 \\
\hline 4 & Germany & 5.645 .581 & 0 & 5.645 .581 \\
\hline 5 & India & 3.952 .550 & 830.346 & 4.782 .896 \\
\hline 6 & South Korea & 3.735 .399 & 379.514 & 4.114 .913 \\
\hline 7 & Mexico & 1.900 .029 & 2.168 .386 & 4.068 .415 \\
\hline 8 & Spain & 2.291 .492 & 556.843 & 2.848 .335 \\
\hline 9 & Brazil & 2.269 .468 & 430.204 & 2.699 .672 \\
\hline 10 & France & 1.748 .000 & 479.000 & 2.227 .000 \\
\hline 11 & Canada & 749.458 & 1.450 .331 & 2.199 .789 \\
\hline 12 & Thailand & 818.44 & 1.170 .383 & 1.988 .823 \\
\hline 13 & UK & 1.671 .166 & 78.219 & 1.749 .385 \\
\hline 14 & Turkey & 1.142 .906 & 552.825 & 1.695 .731 \\
\hline 15 & Russia & 1.348 .029 & 203.264 & 1.551 .293 \\
\hline 16 & Iran & 1.418 .550 & 96.846 & 1.515 .396 \\
\hline 17 & Czech Rep. & 1.413 .881 & 6.112 & 1.419 .993 \\
\hline 18 & Indonesia & 982.356 & 234.259 & 1.216 .615 \\
\hline 19 & Italy & 742.642 & 399.568 & 1.142 .210 \\
\hline 20 & Slovakia & 1.001 .520 & 0 & 1.001 .520 \\
\hline 21 & Others & 536.725 & 221.947 & 758.672 \\
\hline 22 & Poland & 514.700 & 175.029 & 689.729 \\
\hline 23 & South Africa & 321.358 & 268.593 & 589.951 \\
\hline 24 & Hungary & 502.000 & 3.400 & 505.400 \\
\hline 25 & Argentina & 203.700 & 268.458 & 472.158 \\
\hline 26 & Malaysia & 424.880 & 35.260 & 460.140 \\
\hline 27 & Belgium & 336.000 & 43.140 & 379.140 \\
\hline 28 & Morocco & 341.802 & 34.484 & 376.826 \\
\hline 29 & Romania & 359.240 & 10 & 359.250 \\
\hline 30 & Taiwan & 230.356 & 61.207 & 291.563 \\
\hline 31 & Sweden & 226.000 & 0 & 226.000 \\
\hline 32 & Slovenia & 189.852 & 0 & 189.852 \\
\hline 33 & Portugal & 126.426 & 49.118 & 175.544 \\
\hline 34 & Netherlands & 155.000 & 2.280 & 157.280 \\
\hline 35 & Uzbekistan & 140.247 & 0 & 140.247 \\
\hline 36 & Austria & 81.000 & 18.880 & 99.880 \\
\hline 37 & Australia & 88.195 & 10.437 & 98.632 \\
\hline 38 & Finland & 91.598 & 0 & 91.598 \\
\hline 39 & Serbia & 79.360 & 552 & 79.912 \\
\hline 40 & Egypt & 9.970 & 26.670 & 36.640 \\
\hline
\end{tabular}

Source: International Organization of Motor Vehicle Manufacturers http://www.oica.net/category/production-statistics/ (data retrieved on 15.03.2019) 


\section{LITERATURE REVIEW}

Culture is a stable, conservative and flexible force that can only be changed by management intervention (Hatch, 2004). The role of leadership in this model was based on the idea that cultures were stable until the leaders tried to change it (Schein, 1992). However, this action has been accepted as a 'priority task' to create a strategy and structure to reveal the innovative potential. The result of this movement will be a set of innovative fundamental values in organizational culture. For this reason, leadership and management are very important to create a culture that supports innovation and organizational success. Organizational culture drives the organization to an innovative cultural notion. Organizational culture is influential on the level of creativity and innovation in an organization (Ismail and Abdmajid, 2007).

Abdi et al. (2018) examined the direct and indirect effects of organizational culture. Knowledge management and organizational learning on innovation by a study based on the data collected from 279 companies which supply automobile parts to an Iranian leading automobile manufacturer. Their study outlined the influence of organizational culture and knowledge management on organizational innovation.

Sustainable innovation is essential for companies that want to stay profitable and competitive. It is very important to define the relationship between innovation and job performance. The link between innovation and work performance is addressed directly or as part of a broader study in the current literature. The results show a close relationship between innovation and job performance. There has been clear evidence that innovation has a significant impact on long-term profitability and growth in companies (Neely and Hii, 1998).

Leaders must create a culturally friendly environment that encourages creativity and innovation for companies to achieve sustainable innovation. Enterprise innovation depends on how leaders support and manage the diversity of their companies. Leaders are among the most important in-house dimensions that support corporate innovation and corporate success. For this reason, leadership stands as one of the leading elements of internal innovation capability. There is a need for persistent and determined leaders to solidify innovation (Phillips, 2007).

Dixit and Nanda (2011) mentioned the outstanding effect of leadership especially on innovation and creativity in the organizational culture by highlighting that 'it is the duty of organizational leaders to provide culture and environment that feeds and accepts innovation at all levels' and also they are 'supervisors who provide encouragement of creativity by valuing individual's contributions and showing confidence in the work group'. The literature highlights three main factors of group characteristics and key issues of them for us to understand the effect of organizational culture on business success in the same study. Dixit and Nanda (2011) mentioned the importance of leadership and management by revisiting the 
importance of 'selecting and motivating the right employees' based on the outstanding studies from the literature:

- The recruiting, choosing and assignment of people is an important part of encouraging a culture of creativity and innovation in an organization.

- The values and beliefs of management are mirrored to the people who participate in the institution.

At the level of managerial behavior, Brendle (2001) examined the effect of the personality traits of special managers on the support of an innovation culture. business, proactivity, openness to ideas, openness to action and the tendency to take risks revealed that personality traits are the basic conditions for creating a culture that supports innovation.

Fatima (2000) examined the relationship between organizational members' feelings of learning culture and their common cultural behavior and their concerns about the culture of innovation in the public sector in Malaysia. In this study, the importance of leadership in organizational learning and innovation output is emphasized.

\section{METHOD}

\section{Competing Values Framework}

'Competing Values Framework' of Cameron, Quinn and De Graff (2006) was chosen as an instrument to identify the dimensions that provide values at the individual and organizational levels. Competing Values, the framework is cited as one of the 40 remarkable frameworks in the business world. Leading thinkers from major business institutions and companies were examined and tested for a respectable period as 25 years. Moreover, The Competitive Values Framework used today by hundreds of companies worldwide, is the outcome of the work of factors that express the performance of a highly efficient organization (Cameron, Quinn and De Graff, 2006).

Organizational culture profile can be created by identifying the characteristics of culture type by using "Organizational Culture Assessment Tool (OCAI)". In this context, the general cultural profile of an organization comes from one among the four types which are "Clan", "Hierarchy". "Adhocracy" and "Market" (Herzog, 2011). The Competing Values Framework was originally developed from research on key pointers of efficient organizations. The framework was built to investigate:

- Key criteria for defining whether an organization is efficient

- Main factors defining organizational effectiveness

- Judgment of whether an organization is effective (decision criteria) 
It evaluates the culture by asking 4 questions for each of the 6 dimensions below with a total of 24 questions.

- Organizational Leadership

- Management of Employees

- Organization Glue

- Strategic Emphases

- Criteria of Success

- Dominant Characteristics

\section{The Hierarchy Culture}

There are procedures to regulate what people do in such a culture. In this culture, leaders are effective with their good coordination and regulation. Maintaining a smoothly running organization is very important. The long-term concerns of the organization are stability, predictability and efficiency. Official rules and policies bring together the organization. Large organizations and government organizations, government institutions are generally managed by hierarchical culture as proved by numerous standard procedures, multiple hierarchical levels and emphasis on rule reinforcement. However, even in small organizations such as fastfood restaurants, the restaurant can dominate a hierarchical culture. For example, most of the employees are junior employees with often have no training or work experience, and the most prominent feature of the work is the uniformity of products in all areas (Cameron, Quinn, 2005). 
Figure 1: The Competing Values Framework for Culture, Leadership, Effectiveness and Value Drivers

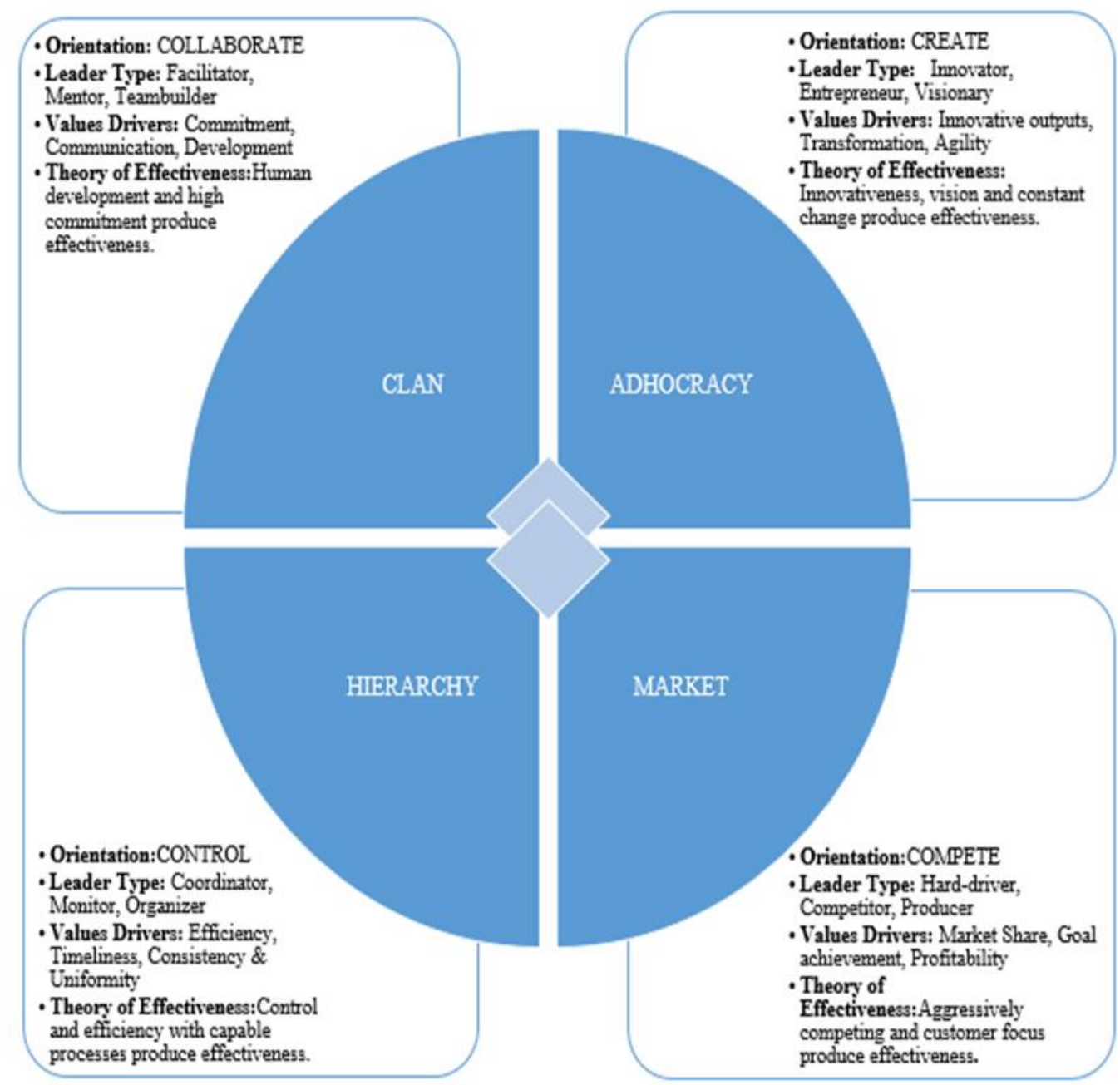

Source: Cameron, K. (2009). "An introduction to the competing values framework". Organizational culture white paper. Haworth.

\section{The Market Culture}

Another shape of organization mostly has been preferred during the last part of 1960s when organizations faced new challenges of competition. This form is based on very different suppositions when it is compared to hierarchy. Organizational researchers have identified alternative activities that underlie organizational activity. The transaction cost is the most prominent one of these. The new design was called a market format. The marketplace is not in the same meaning with marketing functions or consumers in the market. On the contrary, it highlights 
Management and Leadership... $\quad$ DEU Journal of GSSS, Vol: 23, Issue: 2

a functioning organization like market itself. It is canalized to the outside, not to the inside. Suppliers mainly focus on transactions and processes with clients, contractors, licensors, trade alliances and regulators.

Contrary to a hierarchy where internal control is protected by rules, expertise studies and central decisions, the market runs with economic market mechanisms, which consist of major currency changes. In another saying, the main focus of the markets is to trade with other districts (shopping, sales and contracts) that will create competitive power. Profitability, net results, power in market areas, tightness of targets and secure customer bases are the main goals of the organization. As expected, core values that dominate market-based organizations are competitiveness and efficiency. Competitiveness and productivity in market organizations are ensured by a strong emphasis on external positioning and control.

Leaders are challenging and ambitious in this type of culture. They are also demanding. The adhesive that holds the organization together is a winning statement. Long-term concerns are aimed at achieving competitive activities and broad goals. Market share and penetration express success. Moving beyond competition and market leadership is a significant value perception. (Cameron, Quinn, 2005).

\section{The Clan Culture}

This type of culture is like a family type organization, so it is called a clan. The common values and objectives have enabled co-operation and cohesion in the firms with clan culture type. They can be considered as a big community of economic assets. Typical characteristics of clan-type firms are employee collaboration, employee loyalty programs and corporate commitment to employees rather than hierarchical rules and procedures or competitive profit centers of markets. One of the prominent aspects of clan culture is that it empowers its employees and reinforces their participation and loyalty.

Some basic assumptions are that the environment is managed by the best teamwork and employee development, the client is the best partner and within the organization. This culture provides an intimate place for people to whom they share so much, like a big family. Leaders are perceived as mentors and even parental figures.

The organization is organized by loyalty and tradition. Commitment is high. The organization draws attention to the long-term gains of individual development with high commitment and moral importance. Domestic environment and concern for people defines success in this culture type. The organization team demonstrates premiums on work, sharing and concurrence (Cameron, Quinn, 2005).

\section{The Adhocracy Culture}

When the advanced world shifted from industry to contemporary information age, the fourth type of ideal organization emerged. It is the most reactive organization form for the conditions that are increasingly violent, accelerating, 
which symbolizes the organizational world of the twenty-first century. In addition to the dramatically decreasing half-life product and service advantages, different assumptions were developed from the other three organizational forms. These assumptions are that organizations are mainly focused on developing new products and services and preparing them for the future, and that the ultimate task of management is to fortify entrepreneurship, creativity and the environment.

The origin of the word Adhocracy is interim, implying a temporary, special and dynamic thing. Most people work in a special task force or committee that quits when the task is completed. The Adhocracy organization can frequently be observed in sectors such as aviation, programming, consultancy and movie industries. The biggest challenge for these organizations is to produce and develop innovative products and services and to adapt quickly to new opportunities.

Unlike market or hierarchy organizational culture types, there is no centralized relationship between strength or control. Instead, power passes from person to person or from the task team to the task team, depending on which matter has disappeared. The emphasis on individuality, risk-taking, and predictability of the futurity is as high as almost everyone in adhocracy (Cameron, Quinn, 2005).

\section{Research Model}

Our research model is constructed on identifying the management and leadership culture through the two dimensions of competing values framework. The arithmetic mean of the four types of culture in these dimensions will give us a value for the total dimension of management and leadership measurement.

In addition, the presence of four types of culture will be measured for each of the six cultural dimensions and, consequently, for the general organizational culture. General organizational culture includes the arithmetic mean of the four culture types' averages coming from all six dimensions. 
Figure 2: Research Model

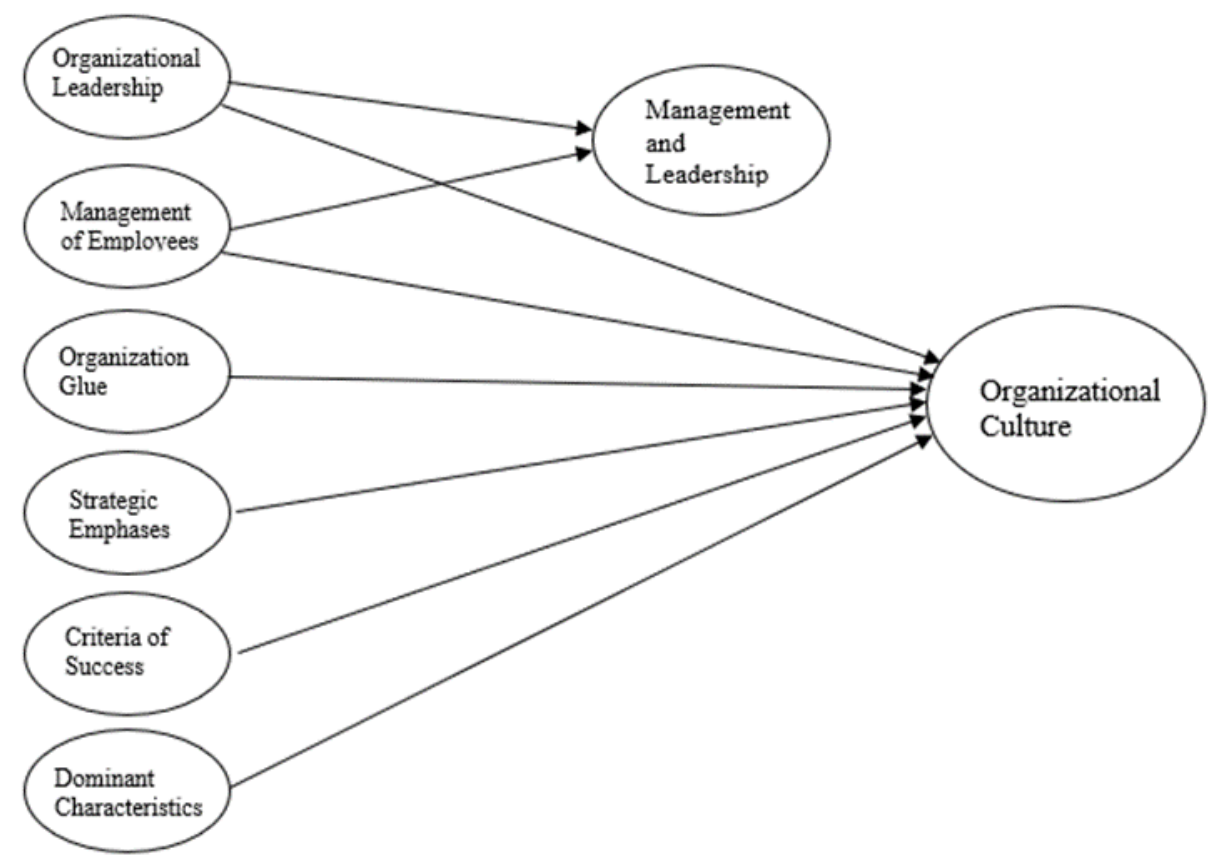

\section{Data Scope}

Our data scope consists of 49 participiants from 3 companies for the described research model. All participiants are from senior professionals with the tenure of 2 years or more. We put this 'tenure criteria' to have results from the employees who can provide significant answers on the companies' cultures.

Table 2: Data Scope Details

\begin{tabular}{|c|c|c|}
\hline Company & Industry & Participants \\
\hline Company 1 & $\begin{array}{c}\text { Automotive Parts } \\
\text { Production }\end{array}$ & $\begin{array}{c}\text { 7 Senior Professionals from R\&D and } \\
\text { Management }\end{array}$ \\
\hline Company 2 & Automotive Production & $\begin{array}{c}\text { 31 Senior Professionals from R\&D and } \\
\text { Management }\end{array}$ \\
\hline Company 3 & Automotive Production & $\begin{array}{c}\text { 11 Senior Professionals from Management and } \\
\text { R\&D }\end{array}$ \\
\hline
\end{tabular}


Okatan, $K$.

DEÜ SBE Dergisi, Cilt: 23, Sayl: 2

\section{FINDINGS}

The implementation of the organizational culture assessment helped us to understand the existence level for each four types of culture at the level of general culture and size.

Figure 3: Organizational Culture Types in Overall Culture

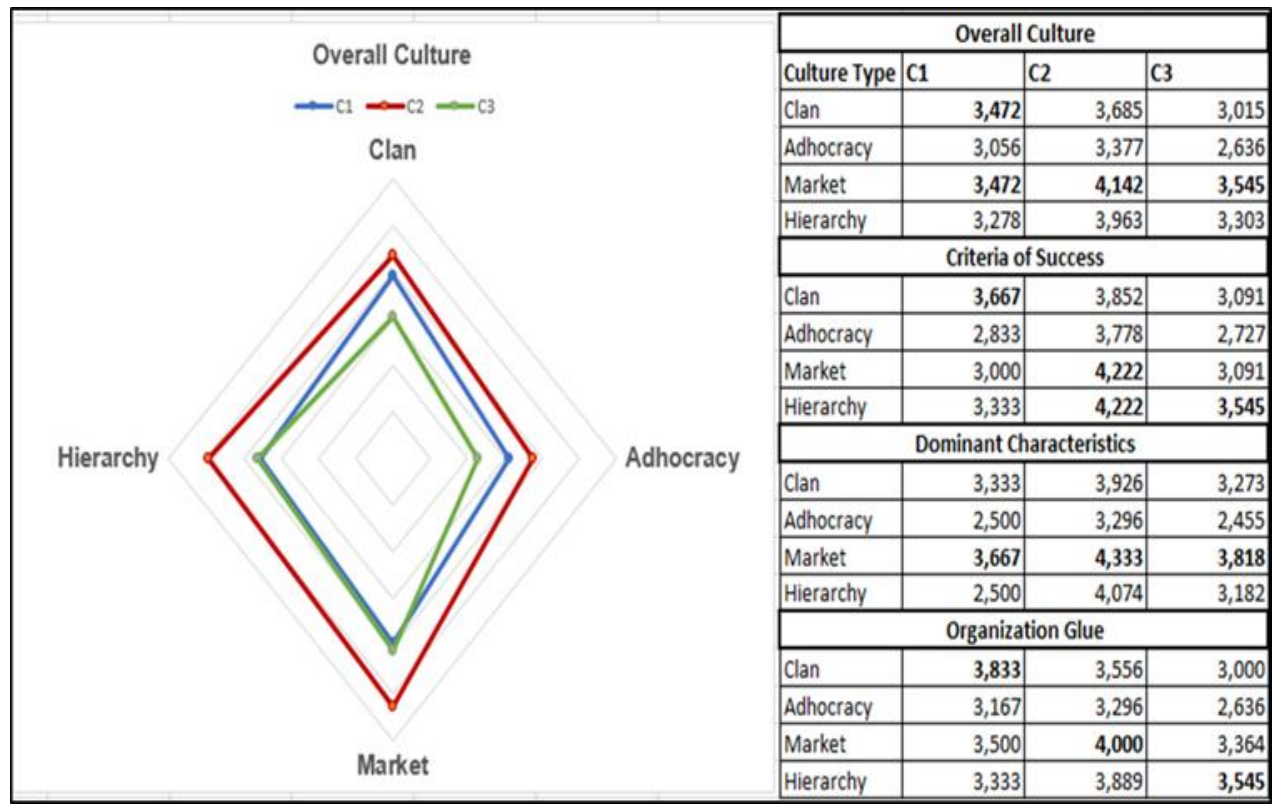

Figure 3 shows the presence levels of four types of organizational culture, which emphasize the dominance of the market culture in all three companies in the organizational culture. Market culture, which focuses on competition between employees and is success-oriented, has predominantly emerged as the most dominant type of culture. However, the clan, culture level of Company 1 is the same as the market culture level. The same figures can be observed from the dominant characteristics of the companies.

We have not been able to observe this parallelism on 'organization glue' and 'criteria of success' dimensions of the organizational culture. It has also been important for us to identify the culture type at 'management of employees' and 'organizational leadership' dimensions since understanding the management and leadership culture type in these companies have been the main focus of this study. 
Dimensions

Figure 4: Organizational Culture Types in Management and Leadership

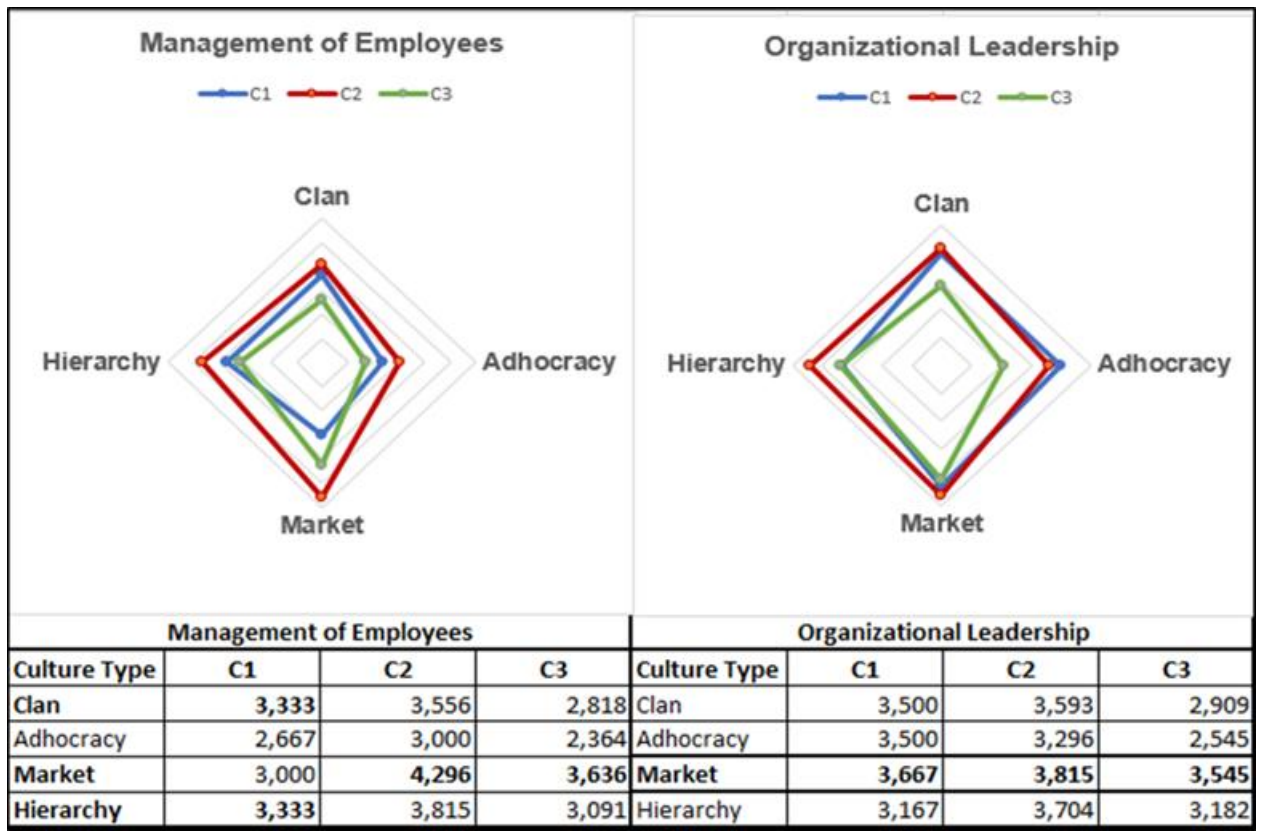

The two dimensions presented parallel shapes with general culture. In particular, organizational leadership offered a complete parallelism with the general culture. This is an expected result, given that organizational leadership has a strong impact on the general culture. Organizational leadership in these companies is emerging as a market culture.

\section{CONCLUSION}

When we examine the organizational culture results of the selected companies, we see that the market culture dominates the management and leadership dimensions of the organizational culture in companies. This view is the same in general culture. The leaders shape the culture of the organization, so it is an expected situation.

It is very clear that the companies vigorously placed the 'customer' into their core of business activities. The 'external oriented' culture strongly evaluates the needs and expectations of the customer with strong feedback mechanism. It is well understood that offering products / services according to customer expectations will bring commercial success.

There is a transparancy on the goals and targets. The leadership clearly communicates the expectations from the employees. The vast majority of employees are aware of what is expected of them and are struggling to achieve them. There is 
strong management assessment fort he employees at specific output and delivery points. It occurs especially for evaluation of achievement and success.

This study has aimed to figure out the type of the culture mainly focusing on 'management of employees and 'organizational leadership' dimensions of the organizational culture in automotive industry. The dominant market culture at management and leadership levels guide us to understand the success orientation and the focus on achievement by fostering competition among the employees. The selected companies with business success concentrate on 'successes' and 'achievements' by injecting them in the cores of the management and leadership. This also ensures the acceptance of the success and achievement as the ultimate goals among the general organizational culture.

Three companies from automotive industry in Turkey were assessed from competing values point of view, in this study. This study contributes to the existing literature by the application of a famous organizational culture assessment framework in order to understand management and leadership culture in a mass production area which requires harmonization of technology and process efficiency for the achievement of business success. On the other hand, independent from the business area it gives us a view to understand the interrelationship of organizational cultural dimensions although the sample size and geographdy can be considered as a limitation. Further studies with more companies and selection from wider industries can be beneficial to understand the organizational culture, management and leadership relationship.

\section{REFERENCES}

Abdi, K., Mardani, A., Senin, A., Tupenaite, L., Naimaviciene, J., Kanapeckiene, L., \& Kutut, V. (2018). "The effect of knowledge management, organizational culture and organizational learning on innovation in automotive industry" Journal of Business Economics and Management, 19(1), 1-19. https://doi.org/10.3846/jbem.2018.1477

Brendle, M, (2001), Personality and company culture: Important contributions to innovation and a source of competitive advantage for small businesses, PhD Thesis, Clemson University, South Carolina, USA

Cameron, K. (2009). "An introduction to the competing values framework". Organizational culture white paper. Haworth.

Cameron. K. S., Quinn. R. E. (2005). Diagnosing and changing organizational culture: Based on the competing values framework. John Wiley \& Sons

Cameron, K. S., Quinn, R. E., DeGraff, J., Thakor, A. V, (2006), Competing values leadership: Creating value in organizations, Edward Elgar Publishing. 
Dixit. G. K., Nanda. T. (2011). "Strategic alignment of organizational culture and climate for stimulating innovation in SMEs" International Journal of Innovation. Management and Technology. 2(1). 77.

Fatima, R, (2000), Perception of learning culture, concerns about the innovation, and their influence on use of an on-going innovation in the Malaysian public sector, $\mathrm{PhD}$ thesis, Georgia University, GA, USA

Hatch. M. (2004). New direction in the study of organizational change and innovation processes. Oxford University Press. New York

Herzog. P. (2011). Open and closed innovation: Different cultures for different strategies. Gabler Verlag. Wiesbaden

Ismail. W. K. W., Abdmajid. R. (2007). "Framework of the culture of innovation: A revisit” Jurnal Kemanusiaan. 9.

International Organization of Motor Vehicle Manufacturers (http://www.oica.net/category/production-statistics/), data retrieved on 15.03.2019

Neely. A., Hii. J. (1998). “Innovation and business performance: a literature review", The Judge Institute of Management Studies. University of Cambridge. 065 .

Phillips, J, (2007), Creating a culture of innovation: changing your culture to accept and embrace innovation. OVO Innovation.

Schein. E. H. (1992). Organizational Culture and Leadership (Vol. 2). Jossey Bass. CA. USA

Thuengnaitham A. (2016). "The effect of internal and external resources on innovative capabilities in Thai firms", Journal of Economics and Sustainable Development. 7(6). 135-142. 